DOI: https://doi.org/10.32839/2304-5809/2019-12-76-64

UDC 811

Ryzhkova Svitlana

Donbas State Teachers Training University

\title{
CONCEPT PARTS IN THE PROCESS OF FORMING OF THE NAMES IN INTERNET
}

\begin{abstract}
Summary. The article deals with the notion of «concept» and cognitive conceptual components in the Internet users' names; the basis conceptual spheres and concrete concepts created by the Internet users in the process of communication have been identified. The author forms his view on the phenomenon of the concept and aims to represent the cognitive components of the concept. Equally important is the analysis of the mechanisms of perception and reproduction of conceptual components with the help of appropriate cognitive models of perception and reproduction of reality. The author singled out the main conceptospheres of the Internet user's name. Anglomovna Internet communication pragne to get to your system is more rapid, symbols and more short form with multiple values. Won are characterized by rapid innovations and widespread social networks, as well as the same characteristics of popularity, creativity,
\end{abstract}

Keywords: internet, communication, concept, conceptualization, cognitive unit.

Рижкова C.B.

Донбаський державний педагогічний університет

\section{КОНЦЕПТУАЛЬНІ СКЛАДОВІ В ПРОЦЕСІ ФОРМУВАННЯ ІМЕНІ В МЕРЕЖІ ІНТЕРНЕТ}

Анотація. У статті розглянуто поняття «концепт» та його когнітивні компоненти в імені користувача мережі Інтернет. Виділено основні концептосфери та конкретні концепти імен учасників Інтернет-спілкування. Автор формуе свій погляд на явище концепту і ставить за мету репрезентацію когнітивних складових концепту. Не менш важливим $е$ аналіз механізмів сприйняття і відтворення концептуальних складових за допомогою відповідних когнітивних моделей сприйняття і відтворення дійсності. Автором виділено основні концептосфери в масиві найменувань в мережі Інтернет. Лексичний склад інтернет-комунікації не тільки утворюе специфічну мовну підсистему, але фрормуеться і закріплюеться за законами і правилами загальнонащіонального мови. При вживанні звичайних слів в інтернет-комунікації відбуваються різноманітні семантичні процеси, широко використовуваний з яких - збільшення або зменшення діапазону значення слова. Англомовна інтернет-комунікащія прагне додати до своєї системи мови більше скорочень, символів і більш короткі форми слів з множинними значеннями. Вона характеризується швидкими інноваціями і поширенням в соціумі, а також має характеристики популярності, креативності, стислості і чіткості. Популярність мови, що належить англомовної інтернет-комунікації, в основному відбиваеться в його словотворенні способом словоскладання і афіксації. Якщо користувач Інтернету розуміє значення афріксів, він може швидко зрозуміти і засвоїти велику кількість неологізмів, отриманих за допомогою афіксації. Іншими словами, використання афіксації і словоскладання робить лексичний склад інтернет-комунікації популярним і доступним для розуміння. Користувачі Інтернету прагнуть вживати скорочені форми слів, абревіації, які служать інструментами економії часу і напруги під час спілкування. Ці ж способи утворення нової лексики можуть виступати як якась особливість певної соціальної групи. Крім того, виділені способи покликані маскувати слова і вирази, які в скороченій формі втрачають свою немилозвучність і трансформуються в явища неформального розмовного стилю, а також здатні грати роль засобу засекречування повідомлення.

Ключові слова: інтернет, комунікація, концепт, концептуалізація, когнітивна складова.

$\mathrm{M}$ odern linguistic concepts are characterized by attempts to discover the universal nature of the language that connects the person with the extra-linguistic reality. Language is a means of conceptualizing this reality, creating a speech picture of the world [2].

Formulation of the problem. The problem with the article is the representation of the concept of a user name of the Internet (hereinafter - IR), the cognitive components of the concept.

The purpose of the article. We form our view of the concept phenomenon and aim to represent the cognitive components of the concept (because in the process of conceptualization of reality involved the cognitive structures that make up the mechanism of conception - ideas), as well as identify the mechanisms of perception and reproduction of conceptual components by means of appropriate cognition models. and reproducing reality and highlighting the main conceptual spheres in an array of names on the Internet. Finally, our task is also to illustrate the specific concepts of Internet communication participants.

Analysis of recent research and publications. The term concept has become actively used in linguistics since the early 90's of XX century. The study of the concept is devoted to the works of Yu.S. Stepanov, A. Vezhbitskoy, J. Lakoff, G.G. Slishkin, V. Karasik and many other scientists.

As noted by S.G. Vorkachev, G.V. Kusov, "the concept includes, in addition to subject attribution, all communicatively meaningful information", namely: paradigmatic, syntagmatic and word-forming connections, pragmatic information and "cognitive memory" words" - semantic characteristics of a speech sign related to the system of spiritual values of native speakers. Today, the term concept is widely used in various fields of linguistic science, in particular, it is included in the conceptual apparatus of cognitive science, semantics, linguocultural studies.

Our appeal to the cognitive, psycholinguistic sciences in an attempt to discover the true nature of 
such a linguistic phenomenon as IR, and the concept represented in it, is due to the fact that the cognitive theory is based, in addition to thinking (its conscious element), on the sensory (sensory) intertwined with the realm of imagination, emotions, the subconscious element of thinking). The IR carrier embodies certain information in its name, often the IR is "emotional" even outside (exclamation marks, capital letters, etc. are used in its design): Kiev-Lady-23_years! AND, K_RA_C_U_H_I.

Presenting main material. The concept - one of the basic concepts of cognitive linguistics, which lies in the field of thinking - the operation of abstract symbols and refers to symbols that relate to the external world - that is, the internal representations of the individual of external reality [1, p. 126]. In other words, with the concept in mind lies the idea and the sensory experience of the individual.

Chronologically, in exploring the concept, science, moving in the direction of form, then in the direction of content, turned to the semantic structure of the phenomenon, abandoning its own structural approach. Much was made of the Prague Linguistic Circle (60's), which worked in the nomination field. Nomination theory is further based on cognitive studies by J. Lakoff, A. Vezhbitskaya, and others $[3 ; 13]$, who have made a significant contribution to the founding and development of cognitive science, where the basic concepts are the categories of the basic level - prototype, frame, module, gestalt, idealized cognitive model (its types) and concept.

One of the first definitions of the concept belongs to A. Vezhbitskaya: The concept is an object from the world "Ideal", which has a name and reflects certain culturally conditioned perceptions of the person about the world and reality" [3].

It most adequately reflects the essence of the "cultural concept" of Yu.S. Stepanov's definition (despite the obvious metaphor): the concept is a kind of "clot of culture in the mind of man, in which form culture enters the mental world of man, that" bundle "of ideas, concepts, knowledge, associations [5, p. 31]. Equally important is the definition of the concept proposed by V.V. Kolesov, according to which the concept appears in its meaningful forms as an image, concept and symbol [4, p. 52].

As V. Karasik notes, "the concept includes object-shaped, conceptual and value components" [2, p. 127]. We consider the value component a central factor that makes the concept meaningful. The degree of significance is determined by the degree of performance. The concept does not arise out of nowhere - it is initially perceived, assimilated, "snatched" from reality, sent to memory and stored in memory (remember frames, file cabinets stored in memory), at the same time the concept refracts in personality, by individual experience, changes, and then reproduces subjectively, begins to live in a speech environment.

We assume that the components of a concept are perceived and reproduced with the help of appropriate cognitive models, namely that the figurative component is a conceptual component that is reproduced with the help of an image-schematic cognitive model. It is a simple assimilation of the concepts of reality through cognitive circuits, such as "good - bad", "far - close", "warm - cold" and images "river - blue ribbon" [3].
This is the so-called "basic conceptualization", which in the process of perception of reality, uses simple schemes and images [4]. The subject component is reproduced with the help of the positional cognitive model. And, finally, the conceptual itself the conceptual component of the concept uses a metaphorical and metonymic cognitive model because it creates some concepts in the "repositories" of others - in other words, imagination is used when, for example, the Needle Free as the wind creates the concept of "freedom", which is conceived by through the metaphorical imposition of "wind is freedom".

V.I. Karasik reduces the conceptual and reverse side of the concept to a "holistic generalized trace" in the memory associated with the object of reality [3, p. 127]. It is about perceived images / objects of reality - in terms of the cognitive sciences they speak of frames / scenarios (objects and situations) of reality and of prototypes - categories of the basic level [3; 2].

The process of describing new life situations does not occur at the expense of inventing a new one, but occurs as a result of using existing samples, including word-forming models, in the process of activating them by analogy. The prototypes of the new name may correspond to several similar structural-semantic models, where there are embedding similar derivatives in word-forming series [2].

Relating the concept of "concept" and "prototype", we can assume that the core of each conceptual sphere is a prototype - a kind of imaginary image, known among other members of the category for its brighter, associative features. It is these brighter, associative signs that are perceived primarily by the cognitive apparatus of the individual.

We consider the conceptual and figurative sides of the concept as two sides, which are responsible for two different stages of the "existence" of the concept the stage of perception and the stage of reproduction. At the stage of reproduction, the conceptual side of the concept can be considered the most important, as the presence of any knowledge, ideas, images already implies. And at the stage of perception, the figurative component of the concept matters more, since gestalt perception (we perceive the world holistically, in the interconnection of components) implies the perception of a holistic image. An image is not a concept, it is a "bundle of interacting features" [3, p. 76]. The image-schematic KM is responsible for such a component.

The conceptual side of the concept can be described using concepts such as frame and gestalt. As noted by V.I. Karasik, "frames are models for measuring and describing knowledge stored in memory" [3]. Modules target frames in language using gestalt (holistic) perception of reality. The linguistic gestalt is described in [5]. We regard linguistic gestalt as a way of correlating form and content; specifically linguistic gestalt expressed (can be expressed), for example, by stylistic means, grammatical structures or other categories of language.

We assume that the means of correlation of meaning and form that we observe in the IP, namely, metaphor, metonymy, various transference of meaning (other examples of gestalt perception are various stylistic methods, such as halophrasis, repetition, epithet, periphrasis, tautology oxymoron) can and should be called the gestalt method or gestalt; The following conclusions can be drawn from the works of J. Lakoff, C. Philmore, and E. Roche [5]. Frames are directly 
data, concepts, representations, etc., which are transformed into a new value by these different methods [4].

Note that the frame is understood as a set of entities, the organization of representations, data structure for the representation of stereotypical representations [4] and gestalt as a way of correlating values with form. In a language frames are subjected to or find a speech form in the structure of the language, some building blocks-modules (these blocks-modules are syntactic, lexical, word-forming structures).

Here are examples of names with implicit ideas that are related to frames. In the frame I want... three dots is the pointer that sets the candidate slot slot "want of desire", I want to get married or I want the bride - the frame slot is "marriage, marriage" (the pointer is to get married, bride).
The frame as a diagram of a typical situation of clichéd, often ritualistic character contains invariant parameters of the situation - terminal (terms) and specific implementations of the parameter of the situation - slots (slots).

Conclusion. It seems to us a prerequisite for revealing the nature of the concept of appealing to the stage of its perception by the individual. As in the process of concept reproduction, cognitive structures (frames of prototypes of reality, objectified in language through modules and linguistic gestures) are involved, as well as in the perception of concepts cognitive structures - some cognitive models of perception of reality. These are the socalled idealized cognitive models (in J. Lakoff's terminology), or PCM.

\section{References:}

1. Stepanov, Yu.S. (1997). Konstanty. Slovar russkoj kultury. Opyt issledovaniya [Constants. The dictionary of Russian culture. Experience of research]. Moscow: Shkola "Yazyki russkoj kultury». (in Russian)

2. Frumkina, R.M. (1992). Koncept, kategoriya, prototip. Lingvisticheskaya i ekstralingvisticheskaya semantika. [Concept, category, prototype. Linguistic and extra linguistic semantics]. Moscow: Nauka. (in Russian)

3. Fillmore, C.J. (1982). Frame semantics. Linguistics in the morning calm: Selected papers from the SICOL. Seoul, pp. 111-137.

4. Rosch, E. (1973). Cognitive psychology. Natural caregories, pp. 328-350.

5. Wierzbicka, A. (1991). Cross-Cultural Pragmatics: The semantics of Human Interaction. Berlin: N.Y.

\section{Список літератури:}

1. Степанов Ю.С. Константы. Словарь русской культуры. Опыт исследования. Москва : Школа «Языки русской культуры», 1997. 356 с.

2. Фрумкина Р.М. Концепт, категория, прототип. Лингвистическая и экстралингвистическая семантика. Москва : Наука, 1992. 245 с.

3. Fillmore C.J. Frame semantics. Linguistics in the morning calm: Selected papers from the SICOL - 1981. Seoul, 1982. P. 111-137.

4. Rosch E. Natural caregories. Cognitive psychology. 1973. P. 328-350.

5. Wierzbicka A. Cross-Cultural Pragmatics: The semantics of Human Interaction. Berlin, N. Y. Mouton de Gruyter, 1991. 389 p. 